\title{
On becoming a psychologist in apartheid South Africa
}

\section{N Chabani Manganyi}

\begin{abstract}
Clinical Psychology training is an arduous journey wherever in the world one pursues it. However, in apartheid South Africa, the experience of becoming a psychologist held its own unique challenges, especially if you were a person of Colour. This article chronicles some of the barriers and hurdles that I had to overcome in order to train as a psychologist in a country where it was almost not expected that Africans could train as clinical psychologists! The story relates some of these training experiences, as well as aspects of my life in exile in the United States, and finally some of my political and related practice experiences in the latter years of apartheid. While many of the professional training challenges that are described may surprise recent Psychology graduates, it is crucial that younger members of the Psychology fraternity are made aware of the history of their profession.
\end{abstract}

\section{Keywords}

Clinical psychology, race, apartheid

The current essay, 'On Becoming a Psychologist in Apartheid South Africa' is an intellectual memoir. It is concerned with my life and work as a clinical psychologist and academic during the dark and sombre years of our lives in apartheid South Africa before the dawn of a new democratic order in April 1994. Within the family of studies described as 'life writing', the present essay falls in the class of writing commonly described as intellectual autobiography. For some obscure reason, intellectual autobiography in its long and short forms has found considerable favour among political economists especially in the essay format which is at issue here. Yet, the widely accepted rationale for writing of this kind, especially among political economists, is that intellectual autobiographies are a worthy contribution to the history of the disciplines concerned. As I see it, an intellectual memoir has a more limited reach than a regular autobiography and can be seen as a lens through which the history and development of one's academic and professional career can be examined while shedding light on the particular history of the discipline concerned. Among psychologists

University of Pretoria, South Africa

\section{Corresponding author:}

N Chabani Manganyi, Unit for Advanced Scholarship, University of Pretoria, PO Box 47I, Wendywood 2I44, Johannesburg, South Africa. Email: chabani@iafrica.com 
and economists, work of this kind, which has attracted my attention includes, Luria's (1979) The Making of Mind, Kegan's (2006) An Argument for Mind, Eysenck's (1997) Rebel With a Cause: The Autobiography of H J Eysenck, and Breit and Hirsch's (2005) Lives of the Laureates: Eighteen Nobel Laureates.

In the present essay and the book which is in preparation, I take a close look at my academic and professional development as a psychologist and academic. In summary, the central organising focus in this work reflects how I moved from one set of academic and professional concerns to others often in response to what I later described as the demands of 'public interest practice' in psychology especially during the decade of the 1980s and the beginning of the 1990s. Undoubtedly, research, writing, and professional choices were made following years of engagement with the discipline and profession of psychology under conditions of legislated exclusion from sectors of the higher education system and professional training in clinical psychology.

The story of my life includes growing up in a rural, traditionalist, non-literate South African countryside community in the 1940s, and most of all, living against an ever-encroaching tide of racial discrimination throughout one's adult life until the mid-1990s. I remember with a sense of relief, a relatively happy childhood as an only child at our home in present day Limpopo. Later at a Swiss Mission boarding school, which was consumed by unrelenting evangelical zeal, I developed an early love of books and reading starting with such texts as The Thirty Nine Steps and The Brothers Karamazov during my final year of high school, encouraged no doubt by our outstanding English teacher Mrs Hill. Douglas Laing Smit Secondary School at Lemana and its small group of outstanding African teachers prepared me adequately for academic success and student leadership roles at the University College of the North to which my generation of Tsonga-, Venda-, and Pedispeaking students were consigned by the Extension of Universities Act of 1959. I completed my bachelor's degree with majors in English and Psychology in 1962. Ironically, at the beginning of 1963, I failed a psychometric test during an interview for a first job at the National Institute for Personnel Research, at that time, a leading centre of research into the psychology of work in Johannesburg. It was that unexpected setback which saw me back at the university in 1963 and 1964 during which time I completed an Honours degree in psychology also conferred at the time by the University of South Africa in Pretoria. In the end, the Honours degree that was conferred was worth the 2 years I spent at the university. In the course of my studies, I had received what I still consider to have been a solid grounding in a number of psychology domains which included developmental psychology, personality theory, psychopathology, research methodology, and therapeutic psychology. I still believe that the 2-year Honours degree that I worked through was a worthy theoretical bridge between undergraduate studies and research-based studies in psychology, which I pursued soon thereafter.

My working career started in earnest in 1965 in Pretoria West following the completion of my studies at the University of the North during the first quarter of 1965. Employed as a Personnel Officer at a Swedish company named Asea Electric, I wasted no time before registering for a master's degree in psychology at the University of South Africa. My research project was entitled 'A comparative study of the psychological needs of a group of African salesmen and factory workers'. Fortunately for me, the disagreements which arose between my promoter Professor F. W. Blignaut and I were resolved expeditiously by the Head of the Psychology Department, Professor A. S. Roux. My dissertation was submitted in January 1969, and I graduated in absentia during that year's winter graduation for Africans.

Without any prior warning, my employment as a human resource officer at the head office of the furniture empire of the Ellerines brothers, Eric and Sydney, in Germiston where I had recently taken on a new position, suddenly came into contention. The source of the dispute between the 
brothers and I revolved around a finding of an investigation I had conducted among predominantly White furniture store managers throughout their company. What raised the anger of the brothers was the fact that I had identified racism as the primary source of the high labour turnover among African sales workers. The long and short of this unpleasant story is that I elected to resign rather than retract the findings of my investigation. That meant that for the first time since I started working in 1965, I was suddenly unemployed. It was then that I approached Professor Hurst, head of the Psychiatry Department at the University of the Witwatersrand at the time, to seek admission into a clinical psychology internship. It turned out that my request was a real shot in the dark because such a request had never been made before. However, what is even more remarkable is that by taking that step, I bade farewell to a future in industrial and organisational psychology. What I had not taken into full account was the fact that in those days, psychiatric hospitals such as Tara in Johannesburg and Weskoppies in Pretoria, catered for White patients primarily and were, for that reason, largely unavailable for the training of Black professionals. Indeed, judging by the course of events which followed my approach to Professor Hurst, it was as if Africans were not expected to train as clinical psychologists!

Nevertheless, Professor Hurst, with the timely assistance of Professor Lipschitz of the Neurosurgery Department at Baragwanath Hospital in Soweto, put together a helpful face saving plan. I was admitted as the first clinical psychology intern at Baragwanath Hospital (now Chris Hani Baragwanath) in January 1969. A significant weakness of the rescue plan, however, was that no provision had been made for any regular supervision of my work as an intern psychologist! There was no established training programme for clinical psychologists at Baragwanath Hospital, and consequently, there was no provision for clinical supervision either. To this day, I cherish the memory of how I was welcomed into the profession of clinical psychology through the back door as I like to put it. In fact, the full implications of the resolution of my predicament arrived at by the two professors only came to light after my arrival at Baragwanath Hospital in January 1969. It was then that I unexpectedly found myself in the midst of neurosurgeons, neurologists, speech and hearing therapists, occupational therapists, and young medical interns. But, and this was the critical issue, there was no psychologist or psychiatrist to supervise my work!

Although I did not fret unduly about the untenable situation in which I found myself, the time had come for me to make the choices that would in the end, be in my interest. One critical factor that counted in everyone's favour was the fact that I was welcomed without reservations into the neurosurgery team! Put in the simplest way, Professor Lipschitz and his professional team let me be. I felt welcomed by the ward sister and her staff as well as the senior professionals. What I witnessed and experienced was the coming together of context (new practical applications of knowledge from different health disciplines that were new to me) and a strong desire on my part to learn and gain maximum benefit from the professional goodwill and help I received from fellow professionals around me. What fascinated me most was their dedication to the well-being of their patients as well as what can be described as the depth of their professional knowledge and skills concerning the well-being of their patients. My daily experiences in the neurosurgery ward were a timely and welcome cure for any reservations I nursed after my arrival at the hospital.

During the 4.5 years I spent first as an intern and later as the first full-time clinical psychologist at Baragwanath Hospital, I appreciated the well-earned professional dedication and selfconfidence which I witnessed among the different groups of professionals who shared their diverse skills treating the patients in Ward 7. I felt singularly privileged to have found myself in the midst of such hard working, highly qualified, disciplined, and talented professionals who were so committed to patient care and well-being. I read extensively especially in the areas of neuropsychology, psycho-somatic disorders, and the literature on the mental status examination in neurology, fields 
which were intimately related to everyday experiences in the hospital wards. In time, I achieved satisfactory levels of proficiency in history taking, interviewing, and clinical report writing in a patient's clinical file. Briefly stated, I learned the languages of neuropsychology and neurology as quickly as I possibly could, especially from the perspective of a clinical psychologist's role as I knew and understood it at the time. What is more, I will always be grateful to the speech and hearing therapists who were at Baragwanath Hospital and the Speech and Hearing Therapy Department at Wits University at the time, for it was their group specifically who introduced me to the fundamentals of clinical neuropsychology during the course of their work with patients recovering from brain injury. It was Wits University trained speech and hearing therapists who introduced me to the work of the Russian neuropsychologist A. R. Luria during a very critical stage of my apprenticeship in clinical psychology.

In retrospect, the experiment of placing an African intern in a teaching neurosurgery ward in a Soweto hospital in the late 1960 s did, contrary to all expectations, work to the satisfaction of those closely concerned with the matter at that time. In fact, the experiment worked so well that on completion of the mandatory year-long internship, I was appointed the first full-time clinical psychologist at Baragwanath hospital. In the course of time, following the completion of my internship, I worked as a consulting psychologist in the neurosurgery unit, the paediatric neurology clinics, and the weekly psychiatry outpatient clinics. During the 4.5 years I worked there, I benefited from working among dedicated, disciplined, talented, and highly qualified men and women. The most senior among them supported my work, challenged me intellectually, and on occasion inspired me to strive for higher academic and professional standards. After the completion of my internship and my master's degree in January 1969, I registered for doctoral studies at the University of South Africa under the supervision of the head of psychology, Professor A. S. Roux. I selected the field of body image among paraplegics: men who had suddenly lost the use of their legs following injury to their spines. I had chosen a theme within a subject in the emerging field of neuropsychology in today's terms. Regrettably, the goodwill which prevailed in the neurosurgery department could not be claimed for race and overall social relations in the daily life and administration of Baragwanath Hospital. In that regard, there was a great deal to be unhappy about. All the statutory racist prohibitions and practices of the apartheid era were enforced unreservedly. There were segregated residences for White and Black professionals, racially segregated eating facilities, ablution, and toilet facilities as well race- and ethnic-based salary scales.

Yet, I am grateful too because much of my professional and academic progress during the Baragwanath years was supported largely by a small group of Black doctors who were engaged in advanced studies in various medical specialties at the University of the Witwatersrand medical school. Consequently, discussions during lunch and tea breaks at the segregated doctor's residence where I lived, covered both professional and everyday political concerns. Colleagues like Dr Benson Nghona, a registrar in medicine at the time, introduced me to the medical school library, to Index Medicus, and one of the best medical bookstores that I have ever used anywhere in the world, which was luckily in the vicinity of the old medical school in Hillbrow. Professor Lipschitz and his team at Baragwanath did exceptionally well in supporting my work as a clinical psychologist throughout the Johannesburg complex of teaching hospitals at the time. But there was more to the Baragwanath experience and experiment. In December 1970, in the course of my regular work at Baragwanath, I completed a doctorate in psychology at the University of South Africa. In academic terms, this was a second milestone since I had, during the year of my internship in 1969, published a paper on hysteria among African women in the South African Medical Journal. Subsequently, in 1972, two articles arising from my doctoral research on body image were published in the Journal of Personality Assessment (Manganyi, 
1972a, 1972b). In 1974, I reported on work closely associated with my doctoral research on body image. On this occasion, the paper was on body image and intellectual maturity in albinism and was written with the collaboration of Professor T. Jenkins and Jennifer Kromberg of the Wits School of Medicine and was published in the Journal of Biosocial Science in 1974 (Manganyi, Kromberg, \& Jenkins, 1974).

By the beginning of the decade of the 1970s, I was beginning to feel restless. My recent successes were a major contributory factor to my uneasiness. I felt that my future professional prospects could be better served in a regular Psychology Department in a university. Yet, all efforts to secure an academic appointment in the Black sector of South Africa's universities as required by law proved futile. Applications at my former university in Limpopo proved singularly unproductive. A significant scene changer when I needed it most was an extended coast-to-coast visit to America's premier universities during the American winter of 1970. As fate would have it, a study tour of numerous clinical psychology training programmes saved me from a looming period of despair. The visit was a once-in-a-lifetime kind of opportunity both in terms of the professionals I was privileged to meet and the large number of psychology departments and universities that were on my itinerary. The most prominent professionals that I met on the east coast, for instance, included psychiatrist Robert Coles at Harvard and the senior most psychologists at Yale University's Connecticut Mental Health Centre who included among others, Daniel Levinson and Sidney Blatt. It was during the time following my working visit to Yale University that I subsequently sought and managed to secure a position as a Post-Doctoral Fellow in the Department of Psychiatry beginning in September 1973.

During the North American summer of 1973, I arrived in New Haven, Connecticut, to take up a Post-Doctoral Fellowship in the psychiatry department at the Connecticut Mental Health Centre. I remember what an uphill battle it was to work on all the psychoanalytic texts that one needed to study while learning and working on a daily basis as a psychotherapist. I remember only too well how we, the arriving Fellows, were each assigned a number of patients and were expected to get on with the work of providing usable help to our clients! Once again, I needed to find my feet as I had learnt to do at Baragwanath Hospital years earlier. Knowing that there were two supervision sessions per week was most reassuring for me in the circumstances. What I needed to get to grips with was the theory and practice of psychoanalytic psychotherapy - the dominant approach to the treatment of mental ill health at the Yale School of Medicine at that time. Remember that the lack of formal training and supervision in psychotherapy during my years at Baragwanath Hospital and the University of the Witwatersrand had been the weakest link in my training until admission to a Yale Post-Doctoral Fellowship. Of greatest assistance to me at Yale then were regular, wellattended seminars on topics such as resistance and transference in treatment relationships. At Yale, unlike at Baragwanath, I came face to face with severely disturbed patients - a far cry from the cases of hysteria that I used to encounter at Baragwanath's medical wards. In due course and with the active support of two senior psychotherapy supervisors, Peter Newton and Daniel Levinson, I was able to work at levels of complexity and depth in my treatment of patients that were well beyond what I could have been able to do back home.

Differences between my South African and American patients were stark. Back home, most of my working-class Black patients often suffered from psychological disturbances presenting as physical illnesses. Unlike at home, where I was limited to working with Black (largely African) patients, at Yale, I came face to face with a wide range of race, class, and ethnic groups among my patients. Back home, palpitations, free-floating anxiety, fear of impending doom, paralysis of limbs, and inability to walk often dominated the clinical picture. In the main, the American patients were afflicted by more severe disorders of the self, conditions commonly seen professionally in 
borderline mental illnesses such as character disorders, which are precariously close to major conditions such as schizophrenia.

I settled in professionally at Yale as I had managed to do under somewhat more difficult conditions back home. Yet, there were moments of excruciating bitterness during the period between September 1973 and July 1975 when my Fellowship came to an end. It was as if I had suddenly discovered that by being in America, the time had come to confront the rage and bitterness I had nursed silently back home. In the 'land of the free', I could be self-consciously angry without having to look over my shoulder. In my fictionalised memoir, Mashangu'Reverie and Other Essays, I recognised that

There was in the beginning of my encounter with America a gross kind of suffering which was gradually transformed into angry anguish. So overwhelming were the fantasies of revenge, so terrifying in their stark clarity, that it became important for me to arrive at some internal resolution of the diverse impulses that were constantly invading my consciousness. I started to write Mashangu's Reverie and The violent Reverie, which may be seen as a frivolous kind of 'self-analysis' and in this way started to rid myself of disturbing impulses. Writing about them transformed them from the realm of the personal to that of the universal.

Nothing could be clearer in the above statement than the fact that the prospect of life in exile in the United States and the anger I had nursed back home kept me awake at night. Indeed, during the 2 years I spent at Yale, there was a prolific outpouring of emotion so much so that I wrote the fictionalised memoir referred to above and its companion essay, The Violent Reverie, as well as a collection of poems (unpublished) and my less well-known book entitled Alienation and the Body in Racist Society (Manganyi, 1977a). The time was ripe, it appeared to me on reflection, to deal with the emotional and psychological baggage that I had carried over the seas on my way to the United States.

I was not surprised by the fact that during the early years of my return home, the years of my involvement with the establishment of what became the University of Transkei (between 1976 and 1981) and later, during my decade long stay at the African Studies Institute of the University of the Witwatersrand where I was a 'Visiting' Professor and Senior Research Fellow between 1981 and 1990, I became preoccupied with the lives of fellow South Africans in exile. It was during the decade of the 1980s that my work on biography was placed on a sound footing. However, a point that is worth emphasising is that well before my return home from the United States in July 1975, I had, as pointed out earlier, tried my hand at autobiographical writing in Mashangu's Reverie (Manganyi, 1977b). By the late 1970s and the decade of the 1980s, I was concentrating on the life stories of Black South Africans who had chosen life in exile rather than live under apartheid back home. I confirmed this early interest and preoccupation with exile and biography during the first international conference on biography at the University of Hawaii in Honolulu in 1981 where I presented my first publication on biography (Manganyi, 1981), which was subsequently followed by my paper on 'Psychobiography and the truth of the subject' in 1983 (Manganyi, 1983b). Since then, I have completed the biographies of Es'kia Mphahlele, Gerard Sekoto, and Dumile Feni. I have undertaken this work because of a belief that I share with the late C. Wright Mills (1959) who believed that personal, that is, private troubles of individuals can throw light on the public concerns and struggles of society at large. I selected biography as a medium because I believe that the personal, that is, private, troubles of the subjects of biography can illuminate a great deal about the everyday concerns of their people. For a society such as South Africa of the recent past, biography can provide testimony and counter-narratives that assert the rights of previously oppressed people in a concerted effort to restore their identity and dignity (Gullestad, 2004). Sustenance for such 
interest in life writing was not difficult for me to find. Apart from the work of C. Wright Mills, I studied the literature on psychohistory and psychobiography represented most prominently in the writings of Erik Erikson (1975), Lifton (1974), and Stannard (1980).

Although I had read some of the foundation texts on psychohistory and psychobiography in the United States and had, as stated earlier, been one of the international speakers at the first international biography conference at the University of Hawaii in Honolulu early in 1981, my involvement with serious biographical research started in earnest with my field work on the life of the South African scholar and writer Es'kia Mphahlele in 1979. Fortunately for me, on my arrival at the African Studies Institute of the University of the Witwatersrand following my headship of the psychology department at the University of Transkei between 1976 and March 1981, I discovered that both Professors Charles van Onslen and Tim Couzens were engaged then in active biographical and social history research. As it turned out, the three of us were a local expression of an international convergence of scholarly interest in biographical research from diverse disciplines.

As far as the practice of clinical psychology after my return home from the United States is concerned, the following is worth noting. During the time I spent as head of the Psychology Department and Dean of the Faculty of Arts at the University of Transkei, there was limited time and opportunities for clinical practice. I was able to see a limited number of referrals from an Umtata doctor who ran a thriving general practice in town. Periodically, I sat in during 'psychiatry' consultations at the Sir Henry Elliot General Hospital in Umtata conducted by a doctor who happened to have an interest in mental illness. Years later, the situation changed for the better after my arrival at the University of the Witwatersrand. I requested and received formal permission from the university authorities to open a limited private practice in the Johannesburg central business district. From then on, my work with patients shifted from public hospital wards to my rooms at His Majesty's Building in Commissioner Street. Needless to say, there was no way of predicting the challenges that would follow the establishment of a private practice in downtown Johannesburg. Notably, it soon became evident that the bulk of my work was no longer with people suffering from psychiatric disorders per se. Many of the referrals who knocked at the door of my consulting rooms were often referred by local law firms. Most often, they complained of neuropsychological impairments such as poor concentration and memory loss following head injuries associated with motor vehicle accidents. In a limited number of cases, such instances were adjudicated in court. A larger number of consultations took place in prisons throughout the length and breadth of our country. Involved in such cases were individuals facing the wrath of the law associated with the widespread public violence and political trials, which became a painful feature of public life during the decade of the 1980s. With my return to Johannesburg during the decade of the 1980s came a new professional challenge, namely, the challenge of work in the field of forensic psychology.

Since my teaching commitments at the university were limited to semester teaching stints in speech and hearing therapy, the private practice became an important new addition to my professional work. My expectations were confirmed when it became clear that the private practice did in due course, enhance the breadth and depth of my scholarly and publishing interests. What follows is a brief picture of the professional and academic life I led during the 1980s.

First, my professional skills were not only in great demand throughout our country. They were tested on a much broader front than at any other time in my career. What did the professional work involve? Some of my work involved the neuropsychological assessment of children and adults following traumatic injuries to the brain. In some instances, such cases required a settlement of the disputes in court in which event, expert evidence needed to be provided. The political struggles of the 1980s and the violence which accompanied them often required expert evidence on extenuating circumstances and mitigation of sentence especially in instances in which capital punishment was 
involved. Work of this kind is a challenge in any court in the world, but it was a more daunting challenge in courts faced with difficult ethical and political questions about just causes, treason, and the right to life. My previous experience in dealing with situations in which I had initially found myself unequal to a task at hand provided me with useful precedents. My answer to hostile challenges in the courtroom, for example, was one I had used before. I relied as I had done during my internship on self-discipline and self-imposed professional rigour, only this time, in my preparation and presentation of expert evidence, ethical integrity and provision of the best information and insights on the questions at hand were crucial. I found answers in the forensic psychology literature on questions regarding the nature of expert evidence in the courtroom, issues on mitigation of sentence, and the nature and structuring of psychological evidence (Haward, 1981). Experience demonstrated the value of procedure protocols, cue books for neuropsychological evaluations, and formats for the presentation of evidence. I had such protocols worked out for reference purposes whenever necessary.

In spite of pressing private practice commitments, I continued to pursue my research interests. The year 1983 witnessed the publication of my first full-length biography, Exiles and Homecomings: A biography of Es 'kia Mphahlele (Manganyi, 1983a). It was followed a year later by a companion volume, a collection of letters entitled, Bury Me at the Marketplace. Then, in the European summer of 1984, I was in Paris on the Left Bank conducting extensive biographical interviews of renowned South African artist Gerard Sekoto. Later that year, I was invited to accept a Visiting Fellowship at Yale University by my former mentor and psychotherapy supervisor Daniel Levinson. I returned to Yale in January 1985. During the course of that year, I taught a semester course on Soviet psychology and psychiatry in one of the Yale colleges. The bulk of my time was spent writing and participating in extensive weekly seminar-type discussions with my host. We had ample opportunities to discuss contemporary theories of biography and work carefully through the interview material I had collected during my visit to Sekoto in Paris. We used Levinson's (Levinson, Darow, Klein, Levinson, \& McKee, 1978) theory of adult development and it's mapping of the phases of adult development as outlined in his book, The Seasons of a Man's Life as a theoretical backdrop for our discussions and analysis of the interview material. We tried to determine for ourselves who the person and artist Gerard Sekoto was.

In June 1985, I took a 2-week break from our work in New Haven to return home. Back home, I was saddened and alarmed by the sheer gruesomeness and vulgarity of the violence that was rampant in Black communities as well as the cold-blooded assassination of South African women, children, and men in neighbouring countries by agents of the apartheid regime. I will always remember 1985 as the year of blood and tears. Individuals known to me had been killed within the country and in Maseru and Gabarone, respectively, by agents of the South African government. On the home front, the gruesome murder of Maki Skhosana by members of a crowd in Duduza (East Rand) in that year left me morally and intellectually agitated. It was the vivid, widely publicised television spectacle of Maki Skhosana's remains burning in an open field with a township urchin on standby that convinced me that something needed to be done by concerned South African psychologists and others about the violence in our communities. At the time of my return to Yale, after my short home visit, I was determined to secure some funding before the end of 1985, for the establishment of a project on my return home. The project would be staffed by a small team of psychologists and would focus on the study and professional treatment of the impact of gross physical and psychological trauma. What was urgently needed were measures and a professional resource capacity to help victims and survivors of violence in an organised and dependable manner. There was a need too, through rigorous research and analysis, to enhance our understanding of the catastrophic mayhem that had descended over our communities and the country as a whole. In 
retrospect, it is much clearer now that I was isolated from 'mainstream' South African psychology during the 1980s. I say this because of the fact that it later turned out that there were several other colleagues even at the university where I worked, who were professionally engaged with the spectre of violence in South African society, yet most of this interest was not public enough to be known by a psychologist working outside the context of regular psychology departments.

The Ford Foundation in New York City responded promptly and positively to my request for funding of what became known as the Political Violence and Health Resources Project at the University of the Witwatersrand. The ardent support of Professor Charles Van Onslen at Wits enabled me and my staff of three psychologists to launch the work of the unit at the beginning of 1987. I continued to work part time at my private practice and in the courts while my colleagues initiated work under my supervision with street children in the Hillbrow precinct of Johannesburg as well as psychological support for families and victims of political violence. The dramatic sequence of events that preceded and followed the surprise release of President Mandela on 11 February 1990 unleashed a chain of events that resulted in the closure of our project at the end of 1990. Yet, before the closure, during the period between 1987 and 1990, we undertook work with the target communities in Johannesburg, successfully organised a noteworthy multidisciplinary conference on political violence and the struggle in South Africa, and with the diligent assistance and editorial skills of Professor Andre du Toit of the University of Cape Town, we edited and published the book Political Violence and the Struggle in South Africa in 1990 (Manganyi \& du Toit, 1990). The success of what was a substantial multidisciplinary social science undertaking at Houw Hoek Inn is ample evidence to illustrate the extent to which violence and political resistance had touched the moral and intellectual sensibilities of a significant number of professionals both in South Africa and abroad.

I want to bring the curtain down at this point for a number of good reasons. The first is that we have been on this story for some time now. The second is that in 1990, I took a self-imposed break from active professional practice as a psychologist. The third and perhaps the best reason for ending the main story here is that in 1991, I published a collection of my psychology papers entitled, Treachery and Innocence: Psychology and Racial Difference in South Africa (Manganyi, 1991). Completed during the last years of my tenure as a Professor and Senior Research Fellow at the University of the Witwatersrand during the late 1980s, the book brought together in a single text, some of the most important theoretical positions I developed and advanced in the course of the late 1970 s and the decade of the 1980s. By the beginning of the 1990s, following several years of training and work both at home and the United States, I felt ready to stand my ground on a number of fronts on matters that were of concern to me such as the training of clinical psychologists, equity in psychological services provision and the practice of psychology in the courtroom. I stated in the introduction that the essays 'reflect my struggles as a psychologist with important questions and represent a biographical statement of a very special kind'.

In conclusion, I would like to say the following. First, the memoir proper will also include a more detailed account of work done during the 1990s and the first decade of the current century, namely, the completion of the second and expanded edition of the Mphahlele letters, the two Gerard Sekoto biographies, and the biography of late South African artist, Dumile Feni. Overall, I am able to say that I spent a very significant part of my life working literally and metaphorically in other people's minds. I have listened to their stories within treatment situations, in maximum security prisons, during the many political trials I was involved in during the 1980s, and in the course of extended biographical research during the decade of 1980s and beyond. Through dedication and wide experience, I learnt the art of listening with the third ear, as we say in the profession. There was much good fortune in my life; the benevolent hand of chance saw me through my first 
awakening at Baragwanath Hospital in Soweto. Equally, there was much good fortune and pain during my brief flirtation with exile in America. The awakening of the mind and the expansion of its horizons happened during my first stay in America all the same. As an academic and mental health worker, I have always tried to be alert to the circumstances in which I do my professional work. Being alert helped me to identify the challenges as well as the academic and practical skills necessary to meet those challenges. By the beginning of the 1990s, I was thinking about a psychology of everyday life, a psychology for and about ordinary women and men, a psychology that is, to advance our society into a non-racist and humane society. I was imagining and proposing what I call a public interest psychology. What we have in this autobiographical essay are glimpses of a working life: glimpses of work themes in psychology and biography in the context of pre-1994 South Africa. I entered the psychology profession through the back door in 1969. I was 'in the soup' for a long time, as Jean Paul Sartre would say. I could think of no better way of ending this autobiographical essay than echoing the words and sentiments of Gail Godwin who once said,

This account of my own unfolding as a writer has been the truth. But it is also full of lies, many of which I'm not aware of. But in one sense, perhaps the most important, it is all true: it could have been written by nobody but me. What I have chosen to tell, how I have chosen to tell it, and what I have chosen not to tell, express me and the kind of writer I am.

How disarmingly true!

\section{Declaration of conflicting interests}

None declared.

\section{Funding}

This research received no specific grant from any funding agency in the public, commercial, or not-for-profit sectors.

\section{References}

Breit, W., \& Hirsch, B. T. (Eds.). (2005). Lives of the laureates: Eighteen Nobel laureates. Cambridge: MIT Press.

Erikson, E. (1975). On the nature of psychohistorical evidence: In search of Gandhi. In E. Erikson (Ed.), Life history and the historical moment (pp. 113-168). New York, NY: W.W. Norton.

Eysenck, H. (1997). Rebel with a cause: The autobiography of Hans Eysenck. New Brunswick, NJ: Transaction.

Gullestad, M. (2004). Tales of consent and descent: Life writing as a fight against an imposed self-image. In P. J. Eakin (Ed.), The ethics of life writing (pp. 216-243). Ithaca, NY: Cornell University Press.

Haward, L. (1981). Forensic psychology. London, England: Batsford Academic and Educational.

Kegan, J. (2006). An argument for mind. New Haven, CT: Yale University Press.

Levinson, D. J., Darow, C. H., Klein, E. B., Levinson, M. H., \& McKee, B. (1978). The seasons of a man's life. New York, NY: Ballantine Books.

Lifton, R. F., \& Oson, E. (Eds.). (1974). Explorations in psychohistory: The Wellfleet papers. New York, NY: Simon \& Schuster.

Luria, A. R. (1966). Higher cortical functions in man. New York, NY: Basic Books.

Luria, A. R. (1979). The making of mind: A personal account of Soviet psychology (M. Cole \& S. Cole Eds.). Cambridge, MA: Harvard University Press.

Manganyi, N. C. (1972a). Body image boundary differentiation and self-steering behavior in African paraplegics. Journal of Personality Assessment, 36, 45-50. 
Manganyi, N. C. (1972b). Projective stimulus ambiguity: Some theoretical and empirical considerations. Journal of Personality Assessment, 36, 5-7.

Manganyi, N. C. (1977a). Alienation and the body in racist society. New York, NY: NOK.

Manganyi, N. C. (1977b). Mashangu's reverie and other essays. Johannesburg, South Africa: Ravan Press.

Manganyi, N. C. (1981). Biography: The Black South African connection. In A. M. Friedson (Ed.), New directions in biography: Essays by Phyllis Auty, Leon Edel, Michael Holroyd, Noel C Manganyi, Gabriel Merle, Margot Peters, and Shoichi Saeki (pp. 52-61). Honolulu, HI: The Biographical Research Center.

Manganyi, N. C. (1983a). Exiles and homecomings: A biography of Es 'kia Mphahlele. Johannesburg, South Africa: Ravan Press.

Manganyi, N. C. (1983b). Psychobiography and the truth of the subject. Biography: An Interdisciplinary Quarterly, 6(1), 34-52.

Manganyi, N. C. (1984). Bury Me at the Marketplace: Selected letters of Es'kia Mphahlele 1943-1980. Johannesburg, South Africa: Skotaville Publishers.

Manganyi, N. C. (1991). Treachery and innocence: Psychology and racial difference in South Africa. Johannesburg, South Africa: Ravan Press.

Manganyi, N. C., \& du Toit, A. (Eds.). (1990). Political violence and the struggle in South Africa. Johannesburg, South Africa: Southern Book.

Manganyi, N. C., Kromberg, J. G., \& Jenkins, T. (1974). Studies in albinism in the South African Negro. Intellectual maturity and body image differentiation. Journal of Biosocial Science, 6, 107-112.

Mills, C. W. (1959). The sociological imagination. New York, NY: Oxford University Press.

Stannard, D. E. (1980). Shrinking history: On Freud and the failure of psychohistory. New York, NY: Oxford University Press. 